\title{
LIBERALISMO, ESTADO, COLONIALISMO E EDUCAÇAO: INTERFACES COM O PASSADO E AS LIÇÕES PARA A ATUALIDADE
}

\author{
Anselmo Alencar Colares ${ }^{(*)}$ \\ Maria Lilia Imbiriba Sousa Colares ${ }^{(* *)}$ \\ Maria José Pires Barros Cardozo ${ }^{(* * *)}$
}

O presente artigo aborda aspectos relacionados a formação e ao desenvolvimento do capitalismo, apontando as interfaces com a colonização posterior aos “Grandes Descobrimentos”, destacando os argumentos apresentados por Adam Smith e David Ricardo ${ }^{1}$ quanto às relações entre Estado (sua vertente econômica) e educação, de tal maneira a instigar o leitor a refletir sobre a atualidade.

Enquanto os objetivos do colonialismo pré-capitalista estavam relacionados com a extração direta de tributos dos povos subjugados, domínio territorial, submissão e escravização das populações, o colonialismo associado ao advento e à expansão do capitalismo teve motivações essencialmente econômicas, embora permeados por interesses de outras ordens. Daí porque, muito mais do que conquistas territoriais, os colonizadores buscavam matéria-prima, novas mercadorias e expansão de mercados consumidores. Não podemos esquecer que a mão-de-obra escrava também constituía uma mercadoria, e das mais valiosas. Isso ajuda a entender o intenso tráfico negreiro movimentado a partir da África e a impetuosa investida contra os índios, resultando em drásticas alterações no modo de vida daquelas populações, cujas conseqüências mais visíveis foram a subserviência ou o extermínio.

Nesse contexto, o Estado ainda não se fazia necessário pois a divisão do trabalho foi transformando-se de espontânea - instrumentos e meios de trabalho ainda pertenciam aos produtores- em planejada- instrumentos e meios de trabalho propriedade privada- modificou as relações mercantis e, consequentemente, provocou modificações no poder político. Por conseguinte, houve a necessidade do poder centralizado de um Estado para preservação das relações mercantis,

\footnotetext{
${ }^{(*)}$ E-mail: anselmo.colares@gmail.com. Orcid: 0000-0002-1767-5640.

${ }^{(* *)}$ E-mail: lilia.colares@hotmail.com. Orcid: 0000-0002-5915-6742.

${ }^{(* * *)}$ E-mail: zezecardozo@ufma.br. Orcid: 0000-0003-0059-7006

1 Smith e Ricardo - dois grandes expoentes do liberalismo clássico - eram ambos vinculados à burguesia nascente em confronto direto com a aristocracia rural e a nobreza, detentoras de monopólios e privilégios que, no contexto mercantilista, dificultavam o livre e pleno desenvolvimento das atividades comerciais.
} 
mediante a coerção política e legal às resistências ao novo modo de produção. Foi necessária também, a (re)organização da educação formal, como mecanismo de integração social, cultural e linguística.

\section{COLONIZAÇÃO E ACUMULAÇÃO DE CAPITAIS}

A escravização e extermínio de indígenas nas Américas, a conquista e a pilhagem nas Índias Orientais, o tráfico de escravos africanos, o rompimento do caráter autárquico da economia do feudo, o uso do dinheiro na comercialização das mercadorias, a união dos comerciantes e mercadores e as guerras mercantis entre os países europeus possibilitaram grande acumulação de riquezas pela burguesia, acelerando o desenvolvimento do modo de produção capitalista.

A exploração colonialista possibilitou a acumulação de capitais em diversos pontos da Europa, especialmente nos países que estavam mais avançados em termos de desenvolvimento industrial, como era o caso da Inglaterra.

No Livro Primeiro de O Capital, publicado pela primeira vez em 1861, Marx (1818-1883) aponta a importância da colonização para a acumulação de capitais:

As descobertas de ouro e de prata na América, o extermínio, a escravização das populações indígenas, forçadas a trabalhar no interior das minas, o início da conquista e pilhagem das Índias Orientais e a transformação da África num vasto campo de caçada lucrativa são os acontecimentos que marcam os albores da era da produção capitalista. Esses processos idílicos são fatores fundamentais da acumulação primitiva. [...] (MARX, 1975, p. 868).

O sistema colonial fez prosperar o comércio e a navegação. As sociedades dotadas de monopólio, de que já falava Lutero, eram poderosas alavancas de concentração de capital. As colônias asseguravam mercado às manufaturas em expansão e, graças ao monopólio, uma acumulação acelerada. As riquezas apresadas fora da Europa pela pilhagem, escravização e massacre refluíam para a metrópole onde se transformavam em capital. [...] (Idem, p. 871).

O conjunto de práticas econômicas desenvolvidas pelos nascentes Estados europeus entre os séculos XVI e XVII recebeu, no século XVIII, a designação de sistema mercantil por parte dos fisiocratas franceses ${ }^{2}$, e os economistas alemães denominaram mercantilismo. O sistema

\footnotetext{
${ }^{2}$ Tendo como principal expoente François Quesnay (1694-1774), os fisiocratas acreditavam ser a terra a única verdadeira fonte de riquezas, segundo uma ordem natural a cujas leis um governo esclarecido deveria submeter-se. "No entanto, o personagem central da economia fisiocrata não é o proprietário rural, como à primeira vista poderia parecer,
} 
mercantilista propiciou o desenvolvimento de mecanismos de concentração de capital nas Metrópoles, com as atividades econômicas das Colônias sendo orientadas segundo os interesses da burguesia comercial da Europa.

Nesse contexto, vê-se bem o significado e a posição das colônias. Elas devem se constituir em retaguarda econômica da metrópole. Pois que a política mercantilista ia sendo praticada pelos vários estados modernos em desenfreada competição, necessária se fazia a reserva de certas áreas onde se pudesse por definição aplicar as normas de política econômica: as colônias garantiriam a autosuficiência metropolitana, meta fundamental da política mercantilista permitindo assim ao Estado colonizador vantajosamente competir com os demais concorrentes.

O projeto colonizador tinha, portanto, sólida urdidura com a mentalidade da época absolutista. Tal objetivo, porém, se constituiu ao mesmo tempo em que se processava concretamente a colonização do Ultramar, onde nem tudo se operava de acordo com as normas em elaboração. A política colonial das potências visava, por isso, enquadrar a expansão colonizadora nos trilhos da política mercantilista; fazer com que as relações entre os dois pólos do sistema (metrópole-colônia) se comportassem consoante o esquema desejável [...] (NOVAIS, 1998, p. 19-20).

A política mercantilista assentava-se na supervalorização dos metais preciosos como insuperável fonte de riqueza; necessidade de ter sempre uma balança comercial favorável, sendo por isso indispensável exportar produtos manufaturados em maior quantidade do que as matériasprimas importadas; desenvolvimento de uma marinha mercante, como garantidora da prática do comércio; desenvolvimento de uma política tarifária e aperfeiçoamento das formas de arrecadação de impostos; intervenção do Estado na economia, impondo restrições ou possibilitando liberdades comerciais, desde que tais decisões pudessem favorecer o desenvolvimento mercantil e industrial.

Através das suas colônias, as metrópoles conseguiam, em certa medida, liberar-se da dependência externa, aumentando a capacidade na disputa comercial e podendo praticar preços que possibilitavam ampliar seu campo de ação.

Garantindo o funcionamento do sistema, o Estado simultaneamente se fortalecia, através da arrecadação de tributos e da montagem da estrutura jurídica e administrativa da qual detinha o controle, sem contar com o privilégio que se reservava de comercializar com exclusividade determinados produtos - o chamado estanco.

mas sim o arrendatário capitalista. Apesar de essa teoria parecer representar a glorificação da propriedade rural (a agricultura é a única atividade produtiva e o produto líquido é o dom da fertilidade da terra) ela é, acima de tudo, uma defesa da atividade capitalista nascente, principalmente agrícola, mas também industrial” (CORAZZA, 1984, p. 17-18). 
Diante desse contexto Hurbeman (1985, p. 84), pontua que:

O Estado nacional predominava porque as vantagens oferecidas por um governo central forte, e por um campo mais amplo de atividades econômicas, eram do interesse da classe média como um todo. Os reis sustentavam-se com o dinheiro recolhido da burguesia, e dependiam, cada vez mais, de seu conselho e ajuda no governo de seus crescentes reinos. Os juízes, ministros e funcionários, em geral, vinham dessa classe.

A exploração colonial viabilizou a transformação do capital comercial em capital industrial, fazendo emergir novas nações hegemônicas e, que conseguiram avançar na produção industrial, ampliando a oferta e as necessidades de mercadorias em nível mundial. Mas não foi uma passagem simples. Conflitos, tensões, rupturas e continuidades marcaram profundamente os três primeiros séculos de nossa história, durante os quais estivemos diretamente subordinados à metrópole portuguesa. O monopólio do comércio exercido pela metrópole exemplifica o grau de subordinação ao qual as colônias estavam submetidas.

Com o avanço da industrialização, as práticas e o pensamento econômico e político adquiriram novas bases e apontaram para novas direções: importava que as colônias se tornassem fornecedoras de matérias-primas e também consumidoras dos excedentes produzidos nos centros industrializados, ou seja, em lugar do jugo político, o que passava a contar era o modo de produzir as mercadorias e o tipo de mercadoria a ser produzida.

A projeção da Inglaterra, especialmente a partir do século XVII resultou da transformação de sua economia e de sua sociedade pela ação articulada dos proprietários de terras, comerciantes e aristocratas, que mobilizaram inteligentemente os recursos nacionais e a mão-de-obra disponível para a obtenção daquele resultado. Fator importante foi a expansão de sua marinha e de sua estrutura industrial, possibilitando-lhe impor-se como fornecedor de produtos industriais para países como Espanha, Portugal e suas respectivas colônias, ao mesmo tempo em que estes serviam de fonte de matérias-primas para a indústria inglesa. Nesse aspecto, podemos utilizar como ilustrativo o Tratado de Methuen, o qual obrigava Portugal a reduzir os tributos sobre as importações de tecidos de lã procedentes da Inglaterra (mais tarde, tais reduções foram estendidas também para as importações de tecidos de lã da França e da Holanda). Em troca, a Inglaterra se comprometia a um tratamento preferencial nas importações de vinhos portugueses sobre os provenientes da França e da Espanha. Methuen serviu para que os alemães e os holandeses fossem desprezados por completo do comércio com Portugal e suas colônias. Desse modo, Portugal foi se tornando extremamente dependente da Inglaterra, a qual obteve grandes ganhos econômicos e políticos, incrementando seus negócios com a China e as Índias Orientais, ao mesmo tempo em que expulsava os holandeses de 
suas principais feitorias naquela gigantesca área. Recebendo metais preciosos de Portugal e da Espanha, grandes compradores de seus produtos industriais, a Inglaterra comprava mercadorias diversas do Oriente, tais como algodão e seda, azeites, sal e outros produtos, alguns dos quais eram reexportados aos países produtores de metais preciosos.

Contando com o poder bélico de sua marinha e as tarifas alfandegárias protecionistas fixadas nas famosas Atas de Navegação (das quais a mais importante foi a de Cromwell, de 1651), os ingleses ampliaram os ganhos econômicos e puderam oferecer produtos industrializados a preços que praticamente impediam o desenvolvimento de quaisquer indústrias em outros países, produzindo grave crise na economia colonial. Além desses obstáculos “naturais”, o governo britânico proibiu, sistematicamente, suas colônias na América do Norte de fabricarem e exportarem produtos industrializados, protegendo assim seu mercado de qualquer eventual concorrência.

Vê-se que a força sócio-político-econômica, ampliando o poderio tecnológico e comercial da Inglaterra, permitia-lhe impor condições de subordinação a outros países que estavam em situação de atraso. Por exemplo, negavam-se a consumir os tecidos orientais. Paralelamente, fazendo uso do seu potencial tecnológico, colocavam nos mercados europeus tecidos a preços mais baixos que os dos demais produtores, provocando grave crise na economia colonial. As demais potências européias praticavam equivalentes formas de aferição de vantagens sobre suas colônias, o que correspondia, na prática, a uma acumulação de capitais em mãos de industriais e grandes comerciantes, impulsionando o sistema capitalista.

Todavia, dado o alto desenvolvimento da estrutura produtiva industrial inglesa, as demais potências coloniais não alcançaram de imediato os mesmos resultados, de tal maneira que, em certa medida, ficaram em uma incômoda posição de subordinação à economia inglesa. Tal circunstância, por sua vez, levava-os a intensificar a exploração sobre suas colônias, inclusive não lhes permitindo desenvolver indústrias que pudessem competir com os artigos que eram produzidos nas respectivas metrópoles.

Portugal não conseguiu desenvolver uma produção industrial em um ritmo que possibilitasse atender a demanda de sua população interna e muito menos de suas colônias, o que fazia com que a Coroa tivesse que despender enorme quantidade de recursos para obter os produtos industriais da Inglaterra e, assim, não conseguia manter com eficiência a sua política mercantilista. Mesmo tendo conseguido, gradativamente, ocupar as terras do Ultramar e fazê-las produzir riquezas, sobretudo com o volumoso comércio de açúcar, Portugal não dispunha de uma frota mercante com capacidade suficiente para fazer cumprir a determinação de que as atividades comerciais ficassem restritas aos 
súditos da Coroa lusa. Além das perdas econômicas resultantes das transações ilegais, também sofria prejuízos ao permitir operações comerciais por navios holandeses e ingleses possibilitando, em contrapartida, o enriquecimento daqueles mercadores.

Autores que expressaram as novas condições resultantes da acumulação de capitais e do desenvolvimento das forças produtivas propuseram mudanças na orientação econômica e política, em favor de uma ampla liberdade de ação do indivíduo, como fundamento para o progresso. Para tanto, a burguesia passou a exercer o domínio no aparelho estatal empreendendo,

[...] a emancipação geral da sociedade a partir da sua situação singular. Essa classe liberta toda a sociedade, mas somente sob a condição de que a sociedade inteira se encontre na mesma situação dessa classe, isto é, por exemplo que possua ou possa adquirir livremente dinheiro e cultura (MARX, 2010, p. 49).

Enfim, a forma vigente de colonização era posta em xeque, uma vez que o capitalismo comercial estava sendo superado pelo capitalismo industrial. A seguir, vejamos os argumentos apresentados por Adam Smith e David Ricardo.

\section{ESTADO E ECONOMIA EM ADAM SMITH}

“Riqueza é poder” diz Smith (1983, v. 1, p. 63) apoiando o que já dissera Hobbes. E o poder está associado diretamente ao objetivo de promover a Riqueza das Nações (título de seu livro, publicado em 1776). A economia política, por sua vez, é considerada por Smith como a ciência de um estadista, cujo objetivo fundamental consiste em “aumentar a riqueza e o poder” nacionais. A ciência econômica assume o objetivo de indicar a maneira como deve o Estado agir para promover o aumento da riqueza. Todavia, Smith considera que o aumento da riqueza nacional depende muito mais de outros fatores que da intervenção do Estado. Por essa razão, sentencia: “A melhor política é sempre deixar as coisas andarem seu curso normal”, uma vez que uma espécie de "mão invisível” se encarregaria de, harmoniosamente, promover o equilíbrio entre oferta e procura, desde que não houvesse obstáculos ao livre desenvolvimento das forças produtivas que operam na sociedade e que são responsáveis pelo crescimento da nação. Por outro lado, Smith admite a intervenção do Estado, quando a "mão invisível” não conseguir harmonizar satisfatoriamente os interesses opostos. O Estado passa a ser então decisivo no sentido de impedir que os conflitos possam prejudicar o desenvolvimento da acumulação do capital e para que possa promover a segurança dos 
proprietários. ${ }^{3}$ Considera que sejam três os “deveres” do Estado: segurança, justiça e obras públicas. (CORAZZA, 1984, p. 25 a 32).

Nas palavras do próprio Smith (1983, p. 147):

Segundo o sistema da liberdade natural, ao soberano cabem apenas três deveres; três deveres, por certo, de grande relevância, mas simples e inteligíveis ao entendimento comum: primeiro, o dever de proteger a sociedade contra a violência e a invasão de outros países independentes; segundo, o dever de proteger, na medida do possível, cada membro da sociedade contra a injustiça e a opressão de qualquer outro membro da mesma, ou seja, o dever de implantar uma administração judicial exata; e, terceiro, o dever de criar e manter certas obras e instituições públicas que jamais algum indivíduo ou um pequeno contingente de indivíduos poderão ter interesse em criar e manter, já que o lucro jamais poderia compensar o gasto de um indivíduo ou de um pequeno contingente de indivíduos, embora muitas vezes, ele possa até compensar em maior grau o gasto de uma grande sociedade.

Nota-se, portanto, que o Estado desempenha um papel importante na acumulação capitalista nascente. E fica claro o compromisso estatal com o interesse capitalista, especialmente quando, em sua obra, trata de questões como a defesa da liberdade de comércio, a tributação e a dívida pública. É possível dizer também que o liberalismo de Smith representa a expressão de um otimismo em relação ao indivíduo, como elemento central do dinamismo que impulsionava a economia no novo sistema. O governo, ao contrário, sendo considerado perdulário e ineficiente.

A visão otimista defendida por Smith, quanto a possibilidade da produção de benefícios gerais para toda a sociedade, caso fosse deixado atuar livremente as forças do mercado, é descrita na figura do açougueiro, em um dos muitos exemplos utilizados em A Riqueza das Nações, para ilustrar o papel do interesse individual como harmonizador e promotor de eficiência e riqueza. Diz Smith, é o interesse do açougueiro, e não a sua generosidade, que garante o fornecimento de meu jantar. Assim, o interesse do indivíduo e a motivação do ganho aparecem como forças que conduzem os homens às atividades que a sociedade está disposta a remunerar. A sociedade distribui

\footnotetext{
3 “É, pois a aquisição de propriedade valiosa e extensa que necessariamente exige o estabelecimento de um governo civil. Onde não há propriedade ou, ao menos, propriedade cujo valor ultrapasse o de dois ou três dias de trabalho, o governo civil não é tão necessário” (SMITH, 1983, p. 164); “O comércio e as manufaturas raramente podem florescer por muito tempo em um país que não tenha uma situação de justiça normal, no qual as pessoas não se sintam seguras na posse de suas propriedades, no qual a fidelidade nos contratos não seja garantida por lei e no qual não se possa supor que a autoridade do Estado seja regularmente empregada para urgir o pagamento das dívidas por parte de todos aqueles que tem condições de pagar” (idem, p. 316).
} 
seus elementos de produção, para atender a necessidades e desejos, através dos mecanismos de mercado (MORAES, 2000, p. 10).

Contudo, para que a liberdade individual de produzir pudesse ser garantida, era necessário um quadro institucional de leis e normas garantido pela autoridade, portanto, pelo Estado. O conjunto de instituições, de normas e leis garantidas pelo Estado seria a condição para o florescimento do comércio e das manufaturas. Isto é, com os seus instrumentos jurídicos e parlamentares evitava 'as perturbações que surgiram na ausência de uma transmissão da propriedade regulamentada- isto é: legalmente prejulgada e santificada-de uma geração à próxima perpetuando também a alienação do controle pelos produtores (MÉSZÁROS, 2002, p. 108).

A produção de riquezas, por sua vez, exige a utilização de força de trabalho, a adequada utilização das forças produtivas, e a aceitação de sua importância pelo conjunto dos trabalhadores. É nesse sentido, em especial, que Smith propõe a ação do Estado no campo educacional.

O homem que gasta toda a sua vida executando algumas operações simples [...] não tem nenhuma oportunidade para exercitar sua compreensão ou para exercer seu espírito inventivo [...] O entorpecimento de sua mente o torna não somente incapaz de saborear ou ter alguma participação em toda a conversação racional, mas também de conceber algum sentimento generoso, nobre e terno e, conseqüentemente, de formar algum julgamento justo até mesmo acerca de muitas das obrigações normais da vida privada. Ele é totalmente incapaz de formar juízo sobre os grandes e vastos interesses de seu país; e, a menos que se tenha empreendido um esforço inaudito para transformá-lo, é igualmente incapaz de defender seu país na guerra. [...] Ora, em toda a sociedade evoluída e civilizada, este é o estado em que inevitavelmente caem os trabalhadores pobres - isto é, a grande massa da população - a menos que o Governo tome algumas providências para impedir que tal aconteça. [...] A educação das pessoas comuns talvez exija, em uma sociedade civilizada e comercial, mais atenção por parte do Estado que a de pessoas de alguma posição e fortuna [...] Com gastos muito pequenos, o Estado pode facilitar, encorajar e até mesmo impor a quase toda a população a necessidade de aprender os pontos mais essenciais da educação. [...] O Estado pode facilitar essa aprendizagem elementar cirando em cada paróquia ou distrito uma pequena escola, onde as crianças possam ser ensinadas (SMITH, 1983, p. 213-215).

Em síntese, Smith, ao definir que a economia equilibra-se em um jogo de oferta e procura, como se uma “mão invisível” a dirigisse, estende para outros ramos econômicos o que os fisiocratas limitavam à agricultura. Formula a teoria do valor-trabalho, mostrando que qualquer trabalho que 
produza mercadorias acrescenta um valor à matéria trabalhada e, por isso, o que proporciona maior riqueza a um país não é o aumento do volume de moedas acumuladas, como pensavam os mercantilistas, mas a ampliação da produtividade mediante a divisão do trabalho. Defende ardorosamente a não intervenção do Estado na economia, mas deixa mostras dos limites do seu posicionamento: os interesses dos proprietários.

\section{ESTADO E ECONOMIA EM DAVID RICARDO}

O inglês David Ricardo em Princípios de Economia Política e Tributação, publicado em 1817, discute, entre outras questões, a diferença entre o valor do trabalho diretamente incorporado a uma mercadoria e o valor desta mercadoria, que também contém os trabalhos aplicados em matéria prima, ferramenta, instalação de fábricas, etc..., isto é, a parte que pertence ao capital. Assim, justifica que, sendo o capitalista (ou proprietário de terras), empregador do trabalho, quem participa da produção com esses itens, deva ter também a sua remuneração, que é o lucro.

Smith, como vimos, havia lançado fortes críticas a intervenção do Estado na economia, reivindicando liberdade de ação para o indivíduo, convicto de que a regulagem mais efetiva do interesse geral só poderia ser exercida pelo mercado. Ricardo amplia esta defesa, substituindo o termo indivíduo por país:

Num sistema comercial totalmente livre, cada país naturalmente dedica seu capital e seu trabalho à atividade que lhe seja mais benéfica. Essa busca de vantagem individual está admiravelmente associada ao bem universal do conjunto dos países. Estimulando a dedicação ao trabalho, recompensando a engenhosidade e propiciando o uso mais eficaz das potencialidades proporcionadas pela natureza, distribui-se o trabalho de modo mais eficiente e mais econômico, enquanto pelo aumento geral de volume de produtos difunde-se o benefício de modo geral e une-se a sociedade universal de todas as nações do mundo civilizado por laços comuns de interesse e de intercâmbio. Este é o princípio que determina que o vinho seja produzido na França e em Portugal, que o trigo seja cultivado na América e na Polônia, e que ferramentas e outros bens sejam manufaturados na Inglaterra (RICARDO, 1982, p. 104).

Além da não intervenção na economia interna, o Estado também não deveria intervir no âmbito das transações externas, por isso, o liberalismo econômico resultante da concepção ricardiana é muito mais enfático quanto à capacidade reguladora do mercado. Sem obstáculos, o mercado revelaria as suas qualidades, em termos de: eficiência, justiça e riqueza. Além dos 
resultados benéficos intrínsecos a estes fatores, tal condição ainda propiciaria paz e harmonia internacional.

Contudo, o Estado não desaparece de sua teoria (chega a dedicar praticamente um terço de sua principal obra para as questões referentes a tributação) uma vez que, os mecanismos naturais de regulação estão sujeitos a obstáculos tais como a baixa fertilidade da terra e a aprovação de leis pelo Estado. Para isto se faz necessário orientar a ação estatal de acordo com as necessidades da acumulação capitalista. Ricardo entende que os gastos governamentais representam apenas uma transferência de despesas do setor privado para o setor estatal. Assim sendo, a despesa estatal não altera o poder de compra total da sociedade, isto é, não exerce qualquer efeito positivo sobre a economia e até mesmo pode representar obstáculos à acumulação, uma vez que tais despesas públicas são realizadas com as receitas obtidas através de impostos. Preocupa-se que os impostos possam transferir recursos que os indivíduos gastariam produtivamente para que o Estado os gaste improdutivamente. Daí sua argumentação centrada na restrição do poder tributário do Estado, como importante fator para a manutenção de seu funcionamento mínimo.

[...] Cada novo imposto se transforma em um novo encargo para a produção e aumenta o preço natural dos produtos. Uma porção do trabalho do país que anteriormente se encontrava à disposição do contribuinte, é colocada à disposição do Estado e, portanto, não pode ser empregada produtivamente. Essa porção pode tornar-se tão grande, que o excedente da produção seja insuficiente para estimular os esforços dos indivíduos que geralmente aumentam o capital nacional com as suas poupanças [...] (RICARDO, 1982, p. 135).

Mas, em determinadas circunstâncias, o Estado deveria ser chamado a atuar na economia, oferecendo proteção aos produtores quando estes fossem ameaçados pela concorrência externa. Tomando como referência as contingências que podem afetar a produção e o comércio do trigo, Ricardo defende como sendo a melhor política governamental

[...] lançar um imposto sobre a importação de trigo estrangeiro, cujo montante fosse gradualmente decrescente durante um número limitado de anos, para permitir ao produtor nacional uma oportunidade de retirar pouco a pouco seu capital da agricultura (RICARDO, 1982, p. 185).

Portanto, mesmo pregando a liberdade de comércio internacional, não descarta a intervenção do Estado para proteger os interesses do capital. Tal posicionamento teórico apenas confirma seus vínculos práticos. 
A força do argumento smitiano foi sendo abalada não apenas pela descoberta de Ricardo das contradições dentro do sistema preconizado por Smith "[...] mas porque os verdadeiros resultados sociais e econômicos do capitalismo provaram ser menos felizes do que tinham sido previstos." (HOBSBAWN, 1977, p. 259). David Ricardo contribuiu de forma decisiva para o fortalecimento da economia política clássica e para colocá-la em lugar de honra no ideário liberal.

A economia política de David Ricardo, uma obra-prima de rigor dedutivo, introduziu [...] consideráveis elementos de discórdia na natural harmonia em que os primeiros economistas tinham apostado. E até mesmo enfatizou, bem mais do que tinha feito Smith, certos fatores que se poderia esperar que detivessem a máquina do progresso econômico, atenuando o suprimento de seu combustível essencial, tal como uma tendência para o declínio da taxa de lucros. E mais ainda, David Ricardo criou a teoria geral do valor intrínseco do trabalho, que só dependia de um leve toque para ser transformada em um argumento potente contra o capitalismo. Contudo, seu domínio técnico como pensador e seu apaixonado apoio aos objetivos práticos que a maioria dos homens de negócios britânicos advogavam - o livre comércio e a hostilidade aos proprietários de terra - ajudaram a dar à economia política clássica um lugar ainda mais firme que antes na ideologia liberal. Para efeitos práticos, as tropas de choque da reforma da classe média britânica no período pós-napoleônico foram armadas com uma combinação de utilitarismo benthamita e economia ricardiana. Por sua vez, as maciças realizações de Smith e Ricardo, respaldadas pelas do comércio e da indústria britânica, fizeram da economia política uma ciência em grande parte britânica, reduzindo os economistas franceses (que tinham, no mínimo, compartilhado da liderança no século XVIII) a um papel menos importante de simples predecessores ou auxiliares, e os economistas não clássicos a um amontoado de franco-atiradores. Além do mais, transformaram-na em um símbolo essencial dos avanços liberais. [...] (HOBSBAWN, 1977, p. 260).

Os Princípios... de Ricardo, revelam seu posicionamento em defesa dos interesses dos industriais, nos quais identificava os interesses da própria nação inglesa. São marcados pela polêmica travada por ele com Malthus (1776-1834), o qual estava vinculado aos interesses dos proprietários de terra. Uma das manifestações da série de controvérsias entre os dois foi com relação à “Lei de Say”, como ficou conhecida a "lei dos mercados” formulada pelo economista francês Jean-Batiste Say (1767-1832) ${ }^{4}$. Ele afirmava que a produção gera sua própria demanda, o

\footnotetext{
${ }^{4}$ Interessante registrar que, em 1808, o Brasil instituiu uma cátedra de economia política, “[...] bem antes da França ocupada por um propagador de Adam Smith, J. B. Say (o principal economista francês) e o anarquista utilitário William Godwin” (HOBSBAWN, 1977, p. 260-261).
} 
que implica não haver restrições de procura efetiva para uma contínua expansão da produção. Tal concepção foi incorporada por Ricardo ${ }^{5}$, embora não tenha representado uma importância central para a sua teorização. Mas teve um peso político, como arma de defesa para o sistema capitalista contra possíveis ataques a outras questões como, por exemplo, a tendência de queda na taxa de lucro, conforme previa Ricardo. Ora, se a acumulação depende dos lucros, cuja taxa tende a cair à medida que progride a sociedade, isto poderia implicar um limite à expansão do "bem-estar social” sob o regime capitalista, daí a contribuição da "Lei de Say": uma vez que ela sustenta a impossibilidade de crises generalizadas de superprodução, convinha aceitá-la como prova de que o sistema capitalista não estaria sujeito a uma crise generalizada.

Corazza (1984, p. 56-59) observa que Malthus, por sua vez, defendia que o crescimento da produção em uma economia capitalista deve fundar-se no crescimento prévio da produção, assim, as crises de superprodução tornam-se perfeitamente possíveis. Ele argumentava que os trabalhadores gastavam toda a renda na subsistência, ao passo que os proprietários gastavam em consumo e "serviços pessoais" e os capitalistas consumiam pouco e gastavam todo o lucro na compra de novo capital. Assim, com o progresso do capitalismo, havia uma tendência de ampliação da renda dos capitalistas, em detrimento dos demais, provocando uma baixa procura efetiva para a produção, uma crise de superprodução. A solução seria, ainda segundo Malthus, adotar políticas de redistribuição da renda, de tal maneira que o capital excedente fosse parar em mãos de consumidores efetivos, ou seja, dos proprietários de terra, classe a qual ele estava vinculado. Chega inclusive a propor a criação de um exército de trabalhadores improdutivos, isto é, trabalhadores que consumam sem que contribuam diretamente para a produção, estando dedicados tanto a "serviços pessoais” dos proprietários de terra, como em serviços tais como reparo de estradas e construção de obras púbicas. Por outro lado, Ricardo não via como essa política de redistribuição pudesse representar uma solução para um eventual problema de demanda.

Um grupo de trabalhadores improdutivos é tão necessário e útil para a produção futura quanto um incêndio que destrua nos depósitos do fabricante as mercadorias que teriam sido, de outra forma, consumidas por aqueles trabalhadores improdutivos [...] Que vantagem teria eu se outro homem que nada me dá em troca consumisse minhas mercadorias? Como é que este consumo me permite auferir lucros? [...] Os capitalistas, para poderem continuar com seus hábitos de poupança, diz o Sr. Malthus, "têm que consumir mais ou produzir menos" [...] As mercadorias consumidas por trabalhadores improdutivos lhes são dadas, e não vendidas em troca de algo [...]

\footnotetext{
5 “[...] mostrou Say, de maneira mais satisfatória, que não há nenhum montante de capital que não possa ser empregado em um país, porque a procura é somente limitada pela produção” (RICARDO, 1982, p. 197).
} 
Retirar 100 peças de roupa de uma fábrica e com elas vestir soldados e marinheiros aumentará os lucros do fabricante? Estimulá-lo-á a produzir? Sim, da mesma forma que um incêndio [...] Se a doutrina do Sr. Malthus fosse verdadeira, o que seria mais aconselhável do que aumentar o exército e duplicar os ordenados dos funcionários púbicos? (HUNT, 1982, apud CORAZZA, 1984, p. 58-59).

Outra polêmica entre Ricardo e Maltus foi quanto as Corn Laws (Leis dos Cereais), que proibia a importação de trigo se o seu preço descesse abaixo de um certo limite. Para Ricardo, importar alimentos era vital para baratear o custo da mão-de-obra e, desse modo, impedir a queda dos lucros. Para Malthus, era vital não importá-los, pois, assim, os lucros baixariam e não haveria uma falta de demanda efetiva, impedindo o surgimento de crises. Estaria também garantida uma renda mais elevada para os proprietários de terra, mediante um preço interno mais elevado dos cereais (sem contar que estaria desestimulado o crescimento da população, uma das suas preocupações centrais). Ricardo venceu: “as Corn Laws acabaram sendo revogadas em 1846 e a partir daí a Inglaterra adotou o livre-cambismo por mais de meio século. Em conseqüência, ela pôde abastecer-se em condições favoráveis de alimentos e matérias-primas nos países pouco ou nada industrializados” (SINGER, 1982, p. XXV).

Ricardo também foi partidário de uma não intervenção do Estado nas relações de trabalho entre capitalistas e trabalhadores. Para ele, o trabalho, como qualquer outra mercadoria, tem seu preço natural e o seu preço de mercado. O preço natural é determinado pela necessidade de sobrevivência do trabalhador e sua família, ao passo que o preço de mercado do trabalho é aquele estabelecido pela interação da oferta e procura. O aumento de salário, portanto, está inteiramente ligado à maior procura de trabalhadores, o que depende do constante aumento da acumulação.

Essas são as leis pelas quais se regulam os salários e pelas quais se orienta a prosperidade de grande maioria dos membros de toda a comunidade. Como todos os demais contratos, os salários deveriam ser deixados à justa e livre concorrência do mercado, e jamais deveriam ser controlados pela interferência da legislação (RICARDO, 1982, p. 87).

Por trás destes argumentos, Ricardo tinha um alvo a combater: as leis dos pobres (Poor Laws $)^{6}$ as quais considerava em total desencontro com as leis naturais do mercado:

\footnotetext{
6 "Série de leis de amparo oficial aos pobres surgidas na Inglaterra em fins do século XV e durante o século XVI. Essas leis foram conseqüência direta das profundas transformações sociais provocadas pela exploração dos recursos naturais do Novo Mundo e a abertura de novos mercados de consumo que favoreceram a expansão do comércio e da indústria manufatureira. Na Inglaterra, a técnica evoluiu, a produção de lã progrediu, a nação se abriu para o processo que dois séculos mais tarde culminaria na Revolução Industrial. E foi essa transformação total nos hábitos e formas de vida a causa principal da proliferação da pobreza, da vagabundagem e da mendicância. Além disso, várias áreas cultivadas,
} 
A tendência clara e direta das leis dos pobres está em total oposição com esses princípios evidentes: não é, como pretendem benevolentemente os legisladores, melhorar a situação dos pobres mas piorar a situação, tanto dos pobres, quanto dos ricos. Em vez de enriquecerem os pobres, elas destinam-se a empobrecer os ricos; e enquanto vigorarem as leis atuais, pela ordem natural das coisas, o fundo de manutenção dos pobres crescerá progressivamente, até absorver todo o rendimento líquido do país, ou, ao menos, tudo quanto o Estado nos deixe depois de satisfazer suas permanentes demandas de fundos para os gastos públicos.

Desde que foi plenamente esclarecida pela pena competente de Malthus, a tendência perniciosa dessas leis já não é um mistério, e todo amigo dos pobres deveria desejar ardentemente sua abolição. Infelizmente, porém, elas foram estabelecidas há tanto tempo e os hábitos dos pobres se ajustaram de tal forma à sua existência, que erradicálas completamente de nosso sistema político exige o maior cuidado e habilidade (RICARDO, 1982, p. 87-88).

Tendo como principais preocupações econômicas a redução do lucro e a provável queda do ritmo em que o capital é acumulado, Ricardo entendia que a lei dos pobres favorecia a acomodação e a multiplicação descontrolada da classe trabalhadora ${ }^{7}$, de tal forma que, se nenhum freio fosse posto, os fundos destinados aos pobres acabariam por absorver todo o rendimento nacional, gerando um “estado estacionário” em que nem a população nem a economia pudessem mais crescer. Por essa razão, entendia que a única garantia de prosperidade para a classe trabalhadora, era o progresso da acumulação de capital, sem qualquer restrição oriunda de medidas tomadas pelo Estado.

Defendia a revogação da Lei dos Pobres, tanto para estimular a produção, como para evitar outras conseqüências mais desastrosas, conforme se pode deduzir deste trecho:

Felizmente estas leis têm vigorado num período de crescente prosperidade, durante o qual os fundos para sustento do trabalho têm aumentado regularmente, estimulando, de modo natural, o aumento da população. No entanto, se o nosso progresso se tornasse mais lento, e se atingíssemos um estado estacionário, do qual acredito

que atendiam à subsistência de inúmeras famílias de camponeses, foram cercadas e transformadas em pastagens. Sem condições para adaptar-se à manufatura ou mesmo à vida urbana, os camponeses perambulavam pelas cidades, sem empregos nem meios de vida" (RICARDO, 1982, nota de rodapé nº 5, p. 87).

${ }^{7}$ Nesse aspecto, há pontos de concordância com Malthus. Vejamos o texto de Ricardo: “[...] o conforto e o bem-estar dos pobres não podem ser permanentemente assegurados sem algum interesse da parte deles ou algum esforço de parte do legislativo, para regular o aumento de seu número e para tornar menos freqüente entre eles os casamentos prematuros e imprevidentes. A vigência do sistema das leis dos pobres tem sido diretamente contrária a isso. Essas leis tornaram toda contenção supérflua e deram estímulo à imprudência, oferecendo-lhe parte dos salários que deveriam caber à prudência e à perseverança.” (RICARDO, 1982, p. 88). 
estarmos ainda muito distantes, então a natureza perniciosa dessas leis se tornaria mais evidente e alarmante. Então, sua revogação seria impedida por muitas dificuldades adicionais (RICARDO, 1982, p. 89).

\section{CONSIDERAÇÕES FINAIS}

A riqueza das nações, de Adam Smith e Princípios de economia política e tributação, de David Ricardo, revelam o pensamento liberal quanto a colonização. A grande meta residia em ampliar os ganhos que a acumulação baseada na lógica mercantilista havia propiciado. Daí as críticas quanto à forte presença e atuação do Estado na esfera econômica e a ênfase na defesa da liberdade de atuação dos indivíduos. Apesar das críticas de Smith e Ricardo ao mercantilismo, não houve interesse naqueles autores em alterar o quadro geral de subordinação das colônias com relação às metrópoles, mas, fundamentalmente, em apontar caminhos para acelerar o progresso que a acumulação de capitais permitia.

Vejamos as elucidativas observações de Eric Hobsbawm.

O argumento social da economia política de Adam Smith era tanto elegante quanto confortador. [...] Podia ser cientificamente provado que a existência de uma classe de capitalistas donos dos meios de produção beneficiava a todos, inclusive aos trabalhadores que se alugavam a seus membros, exatamente como poderia ser cientificamente comprovado que os interesses da Grã-Bretanha e da Jamaica estariam melhor servidos se aquela produzisse mercadorias manufaturadas e esta produzisse açúcar natural. O aumento da riqueza das nações continuava com as operações das empresas privadas e a acumulação de capital, e poderia ser demonstrado que qualquer outro método de assegurá-lo iria desacelerá-lo ou mesmo estancá-lo. Além do mais, a sociedade economicamente muito desigual que resultava inevitavelmente das operações de natureza humana não era incompatível com a igualdade natural de todos os homens nem com a justiça, pois além de assegurar inclusive aos mais pobres condições de vida melhores, ela se baseava na mais eqüitativa de todas as relações: o intercâmbio de valores equivalentes no mercado. [...]

O progresso era, portanto, tão "natural” quanto o capitalismo. Se fossem removidos os obstáculos artificiais que no passado lhe haviam colocado, se produziria de modo inevitável; e era evidente que o progresso da produção estava de braços dados com o progresso das artes, das ciências e da civilização em geral. Que não se pense que os homens que tinham tais opiniões eram meros advogados dos consumados interesses dos homens de negócios. Eram homens que acreditavam, com considerável 
justificativa histórica neste período, que o caminho para o avanço da humanidade passava pelo capitalismo (HOBSBAWM, 1977, p. 259).

Neste texto, realizamos as reflexões tendo como referenciais dois grandes autores da economia política clássica: Adam Smith e David Ricardo. Embora seus escritos pertençam aos séculos XVIII e XIX - portanto, respondendo às questões postas naquela época, no contexto ao qual estavam vinculados e de acordo com as suas convicções teóricas e os interesses da classe a qual se vinculavam - ainda dão suporte para o pensamento liberal em nossos dias, uma vez que a defesa da propriedade privada, da não intervenção do estado na economia (salvo em certas circunstâncias necessárias ao próprio capital), a apologia do mercado baseada na crença de suas leis, continuam a ser pontos de convergência sobre os quais se entendem todos aqueles que não precisam vender a si próprios como mercadorias. A obra de David Ricardo, em especial, nós dá a sensação de que, várias de suas recomendações estão atuais, vivas e circulando vitoriosamente, inclusive no que se convencionou chamar de neoliberalismo. Pensar sobre estas questões, buscando entender as interfaces do Estado com a economia, são fundamentais para que possamos melhor compreender outros temas, entre os quais destacamos a educação, pois esta política social gestada no estado capitalista tende a configurar-se segundo os interesses do mercado, ou seja, ressaltando o individualismo e defendendo a liberdade e a igualdade como valores antitéticos (BOBBIO, 1993). 


\section{REFERÊNCIAS}

BOBBIO, Noberto. Liberalismo e democracia. São Paulo: Brasiliense, 1993.

CORAZZA, Gentil. Teoria econômica e estado (de Quesnay a Keynes). Dissertação de Mestrado. Faculdade de Ciências Econômicas, UFRS, Rio Grande do Sul, 1984.

FERRO, Marc. História das colonizações: das conquistas às independências séculos XIII a XX. Tradução Rosa Freire D’Aguiar. São Paulo: Companhia das Letras, 1996.

HOBSBAWM, Eric. A era das revoluções: Europa 1789-1848. Tradução Maria Tereza Lopes Teixeira e Marcos Penchel. Rio de Janeiro: Paz e Terra, 1977.

HUBERMAN, Leo. História da riqueza do homem. Rio de Janeiro: Zahar Editores, 1985.

MARX, K. Contribuição à crítica a filosofia do direito de Hegel: introdução. São Paulo: Expressão Popular, 2010.

MELLO, Alex Fiúza de. Marx e a globalização do capitalismo. Tese de Doutorado. Instituto de Filosofia e Ciências Humanas, UNICAMP, Campinas, 1998.

Modo de produção mundial e processo civilizatório: os horizontes históricos do capitalismo em Marx. Belém: Paka-Tatu, 2001.

MÉSZÁROS, I. Para além do capital. São Paulo: Boitempo, 2002.

MORAES, Reginaldo C. Corrêa de. Liberalismo clássico: notas sobre sua história e alguns de seus argumentos. Campinas: IFCH/UNICAMP. Textos didáticos nº 40, jan. de 2000.

NOVAIS, Fernando A. Portugal e Brasil na crise do antigo sistema colonial (1777-1808). 2 ed. São Paulo: Hucitec, 1989.

RICARDO, David. Princípios de economia política e tributação. São Paulo: Abril Cultural, 1982. [Tradução de Paulo Henrique Ribeiro Sandroni]. Coleção os Economistas.

SINGER, Paul. Apresentação. In: RICARDO, David. Princípios de economia política e tributação. São Paulo: Abril Cultural, 1982. [Tradução de Paulo Henrique Ribeiro Sandroni]. Coleção os Economistas.

SMITH, Adam. A riqueza das nações: investigação sobre sua natureza e suas causas. São Paulo: Abril Cultural, 1983. 


\section{RESUMO}

Este artigo discorre sobre algumas questões acerca do desenvolvimento do capitalismo e suas interfaces com o Estado a partir de estudos bibliográficos das obras $A$ riqueza das nações, de Adam Smith e Princípios de economia política e tributação, de David Ricardo. Apresenta como esses autores revelam o pensamento liberal quanto a colonização e a intervenção do Estado. Conclui-se que a obra de David Ricardo, em especial, revela que várias de suas recomendações e assertivas quanto à defesa do liberalismo estão atuais, vivas e circulando vitoriosamente, inclusive no que se convencionou chamar de neoliberalismo. Portanto, considerase pertinente refletir sobre estas questões, buscando compreender que as interfaces do Estado com a economia, são fundamentais para que possamos melhor compreender outros temas, entre os quais destacamos a educação.

Palavras-chave: Estado. Liberalismo. Colonialismo. Educação.

\section{LIBERALISM, STATE, COLONIALISM AND EDUCATION: INTERFACES WITH THE PAST AND THE LESSONS FOR TODAY}

\section{ABSTRACT}

This article discusses some issues about the development of capitalism and its interfaces with the State from bibliographic studies of the work $A$ riqueza das nações, by Adam Smith and Princípios de economia política $e$ tributação, by David Ricardo. It shows how these authors reveal the liberal thought about colonization and State intervention. It is concluded that the work of David Ricardo, in particular, reveals that several of his recommendations and assertive as to the defense of liberalism are present, alive and circulating victoriously, including what is conventionally called neoliberalism. Therefore, it is considered appropriate to reflect on these issues, seeking to understand the interfaces between the State and the economy are fundamental so that we can better understand other subjects, among which we highlight the education.

Keywords: State. Liberalism. Colonialism. Education. 